\title{
A Comparative Study of Police Government Microblog and Government Tik Tok
}

\author{
Ainan $\mathrm{Zhu}^{1}$, Xia $\mathbf{L i}^{2}$ \\ 1People's Public Security University of China, Beijing 100038, China. \\ 2School of foreign languages, Chongqing Normal University, Chongqing 401331, China.
}

Abstract: Based on "government micro-blog" and "government tiktok" of Chinese Police Online, this paper collects data with the help of Octopus Collector and Python, then studies the status quo of Chinese police on-line through two new government media platforms: Weibo and Weibo public security organs to use new media to carry out government propaganda and public opinion guidance and control work.

Keywords: Public Opinion of Public Security; Government Tiktok; Government Micro-Blog;

\section{Introduction:}

In recent years, as important new media of government affairs, government micro-blog and government tiktok can respond to public opinion concerns in a timely and effective way, and effectively guide public opinion, playing a very important role in social security governance. In order to give full play to the role of new government affairs media in guiding and controlling public opinions on criminal networks, it is necessary for us to conduct in-depth analysis of new government affairs media and make targeted optimization and improvement.

\section{Research design and research methods}

In order to study the similarities and differences between tiktok and weibo in government affairs communication, public opinion management and control, this paper takes tiktok and weibo in government affairs online of Chinese police as the research objects, to collect data (basic data is shown in Table 1) and do quantitative analysis on Chinese police online government tiktok and government micro-blog from November 1 to 30, 2020 by means of octopus data collector and Python tools ${ }^{[1]}$.Then, a comparative study is made between Chinese police online government micro-blog and tiktok, discussing the characteristics and differences of information dissemination. For the research methods, I use statistical analysis method and text analysis method.

Table 1 Basic data of Chinese police online government micro-blog and government tiktok

\begin{tabular}{|c|c|c|c|c|c|}
\hline New media & Name & $\begin{array}{c}\text { Number of fans } \\
\text { (ten thousand) }\end{array}$ & $\begin{array}{c}\text { Quantity of data } \\
\text { collected (pieces) }\end{array}$ & $\begin{array}{c}\text { Remarks of Government } \\
\text { Media }\end{array}$ & $\begin{array}{c}\text { Data collection } \\
\text { time }\end{array}$ \\
\hline
\end{tabular}

Copyright (C) 2020 Ainan Zhu et al.

doi: $10.18282 / 1-e . v 9 i 4.1738$

This is an open-access article distributed under the terms of the Creative Commons Attribution Non-Commercial License (http://creativecommons.org/licenses/by-nc/4.0/), which permits unrestricted non-commercial use, distribution, and reproduction in any medium, provided the original work is properly cited.

laboratories in colleges and universities. It should become a prerequisite part of the safety construction in pharmaceutical laboratories because it can guarantee the normal teaching and research in colleges and universities. As part of the safety management system of pharmaceutical laboratories, the importance and development direction of safety management should be clearly comprehended so that in future, great effort could be made to strengthen top-level design, cultivate high-end pharmaceutical talents and promote the development of pharmaceutical sciences.

\section{References}

[1] Tian Chenning, Li Hongxia, Tian Shuicheng, Tian Fangyuan. (2020). Risk Assessment of Safety Management Audit Based on Fuzzy TOPSIS Method[J]. Mathematical Problems in Engineering, 2020, 1-11.

[2] Wang Houmiao. (2019). Analysis of University Laboratory Safety Status and Management Strategy[J]. The Science Education Article Collects, 2019(10), 26-27.

[3] Su Ruxiang, Yang Ruixia. (2019). Exploration on the Safety Management Mode of University Laboratories[J]. Chemical Enterprise Management, 2019; (12), 93-97.

[4] M.S. Keckler, K. Anderson, S. McAllister, J.K. Rasheed, J. Noble-Wang. (2019) Development and Implementation of Evidencebased Laboratory Safety Management Tools for A Public Health Laboratory[J]. Safety Science, 2019; (117), $205-216$. 


\begin{tabular}{|c|c|c|c|c|c|}
\hline $\begin{array}{c}\text { Government } \\
\text { micro-blog }\end{array}$ & \multirow{2}{*}{$\begin{array}{c}\text { China Police } \\
\text { Online }\end{array}$} & 3150 & 642 & \multirow{2}{*}{$\begin{array}{c}\text { Public Security } \\
\text { Administration }\end{array}$} & 2020.12 .5 \\
\cline { 1 - 3 } $\begin{array}{c}\text { Government } \\
\text { tiktok }\end{array}$ & & 456.7 & 20 & & \\
\hline
\end{tabular}

\section{Comparative analysis based on research objects}

The author compares the characteristics of government micro-blog and government tiktok in the process of information release and dissemination from two perspectives: text analysis, and the analysis of single burst point information.

\subsection{Text analysis}

With the help of octopus collector, the author crawled the content of this micro-blog posted by China Police Online in November, extracted the tiktok text of November by hand then the corresponding text libraries are made respectively. After manual identification and elimination of blog information irrelevant to the organization's theme, no actual content (such as: Weibo video, 2020, November, etc.), repeatedly forwarded and other content. Then, with the help of the Jieba word segmentation module of Python, the selected China Police Online government micro-blog database and government tiktok text database are respectively analyzed, and a total of 4557 government micro-blog data and 228 government tiktok text data are obtained.

After the above processing, the precise mode of Python's Jieba word segmentation module was adopted to conduct a statistical analysis of word segmentation and word frequency of China Police Online government micro-blog and government tiktok text database, and the top 5 words were ranked according to word frequency from high to low, and Table 2 was obtained.

Table 2 Top 5 statistics of high-frequency words in China Police Online government micro-blog and government tiktok

\begin{tabular}{|c|c|c|c|c|}
\hline Sort & Government $\mathrm{N}$ & Micro-blog & Government & Tiktok \\
\hline 1 & China & 81 & Special police & \\
\hline 2 & Safety & 79 & Hong Kong & \\
\hline 3 & Police & 66 & China & \\
\hline 4 & People's policemen & 60 & Guard & \\
\hline 5 & Law and order & 55 & MP & \\
\hline
\end{tabular}

Statistical analysis based on the text analysis of high frequency words found that China Police Online tiktok and government micro-blog also exist difference in information expression, high-frequency words coincidence degree is low. However, when we compare the frequency of the high-frequency words in government tiktok with government micro-blog in the same paragraph, it is found that the frequency of the two words is highly unified, reaching about $80 \%$. Through further analysis, we found that although the China Police Online government tiktok and government micro-blog in the daily operation of daily release quantity, content have big difference ${ }^{[1]}$.

\subsection{Analysis of single "breakout point" information}

When the public is faced with an unexpected criminal incident, a micro-blog or a short video released by the public security organ may attract a large number of Internet users to forward, comment or thumb up below, thus forming a single "explosive point" information. According to the analysis of single "burst point" information, we can roughly understand the type and characteristics of government information that Internet users prefer, which is helpful for public opinion guidance of new media on government affairs. Through comparative study, it is found that there are significant differences between tiktok and Weibo in the dissemination of single "pop point" information, and the root cause of the differences is related to the characteristics of information dissemination of Weibo and tiktok.

In this paper, the micro-blog messages released by China Police Online government micro-blog are ranked according to the principle of the sum of the most forwarding volume, comments and number of likes, and the first three "explosive points" information are selected (Table 3).

\begin{tabular}{|c|c|c|c|c|}
\hline Release time & Publication content & $\begin{array}{c}\text { forwarding } \\
\text { volume }\end{array}$ & comments & $\begin{array}{c}\text { Number } \\
\text { of likes }\end{array}$ \\
\hline 12 November & $\begin{array}{c}\text { \#At least ten provinces across the country have banned parents } \\
\text { from correcting homework, and some have incorporated it into } \\
\text { schoolperformance management\# }\end{array}$ & 122 & 291 & 17945 \\
\hline 21 November & $\begin{array}{c}\text { \#The story of Police's anti-epidemic Story\#12 houes to fight the } \\
\text { epidemic\# Ethereal Sound The theme of this issue. }\end{array}$ & 2005 & 722 & 8449 \\
\hline 18 November & $\begin{array}{c}\text { \#Policemen teach you new knowledge\# How to Close Computer } \\
\text { Spam LChina Police Online Weibo video }\end{array}$ & 3412 & 341 & 4798 \\
\hline
\end{tabular}

Through the analysis, it is found that the time and topic of burst point are relatively scattered. I believe that the relatively 
dispersed reasons are caused by the large number of public security government micro-blog posts and the wide range of themes of public security government propaganda. As mentioned above, we have concluded that the number of posts posted on the China Police Online government micro-blog was nearly 22 every day in November, covering a long period of time. In the theme of the post, the main content is criminal crimes, public security violations, but also includes about education, military, parent-child life and other topics. A large number of published articles and the diversification of published topics have narrowed the distance between the public security department and the people, so that it can timely report and publicize social hot spots to the public, and at the same time grasp and collect people's views and attitudes towards hot events.

The short videos released by China Police Online government tiktok, were ranked according to the principle of the sum of the forwarding volume, comments and number of likes (Table 4).

Table 4 "Exploding Points" Information of government tiktok of China Police Online

\begin{tabular}{|c|c|c|c|c|}
\hline Release time & Publication content & $\begin{array}{c}\text { forwarding } \\
\text { volume }\end{array}$ & comments & $\begin{array}{c}\text { Number of } \\
\text { likes }\end{array}$ \\
\hline 22 November & $\begin{array}{c}\text { Big news! Involved in illegal procession on Hong } \\
\text { Kong Island. Hong Kong Shatin District Councilman } \\
\text { Lee Chihong arrested! \# Protect Hong Kong }\end{array}$ & 84 & 100 & 45000 \\
\hline 21 November & $\begin{array}{c}\text { Tu Boyi, an old volunteer soldier, was attacked by an } \\
\text { enemy gasoline bomb and burned extensively. }\end{array}$ & 28 & 230 & 30500 \\
\hline $\begin{array}{c}\text { Auxiliary police hold more than 60 children over the } \\
\text { water, praise \# salute the ordinary hero. }\end{array}$ & 6 & 17 & 23644 \\
\hline
\end{tabular}

Information about "exploding spots" is relatively concentrated. This is mainly reflected in the concentration of time and event theme, and the concentration of time and theme is inseparable from hot events. In terms of concentration of time, government tiktok's "exploding point" information focused on November 17 to November 21; In terms of the focus on the subject of the event, the theme of these "flashpoint" messages is related to the Hong Kong issue and the anti-American aid to the DPRK. In the form, the content of "explosive point" is mainly forwarded.

\section{Conclusion and Prospect}

\subsection{Accurate positioning and building a linkage mechanism}

At present, the number of active days in China is huge, almost three times that of Weibo, but the number of government Weibo released by the Chinese police online on the same day is $31 \%$. of the real government chatter .9 times, it is clear that the great communication power of the Chinese police online government affairs shake sound has not been effectively used, and there is no linkage mechanism between government tiktok and government micro-blog. In order to maximize the communication power of public security government affairs, it is necessary to construct the new media linkage mechanism of public security government affairs at this stage ${ }^{[2]}$..

\subsection{Increased user interaction and shaping IP}

The new media of public security government affairs must rely on the continuous interaction between the user and himself in order to stick together with the public and give full play to the value of its government affairs communication and public opinion control. Therefore, it is necessary to strengthen the mutual communication between the public security government media number and the Internet users, enhance understanding and increase feelings through mutual dialogue. Let the public take the initiative to participate in the topic, activities, everyone in the activities to comment on each other, stimulate the subjective initiative of the public, enhance the public voice opportunities and abilities.

\subsection{Optimizing content arrangement and improving content quality of new media}

With regard to arrangement, we should synthesize the number of likes, comments and retweets of short video from different government agencies, and refer to the formula of "interaction index" of Qingbo big data DCI (V1.0): let the number of short video likes be "x1", comment number is " x2", share number is "x3", then "interaction index $=0.4 * 1 \mathrm{n}(\mathrm{X} 1)$. The 1)0.45*1 n X2 1) $0.15^{*} 1$ $\left.\mathrm{n} X 3{ }^{1}\right)^{[3]}$. To analyze the difference between different types of short video interaction ability, and get the content characteristic framework. In terms of quality, we must resolutely prevent formalism such as heavy quantity and light quality, heavy flow and light connotation ,re-distribution and light interaction and so on.

\section{Reference}

[1]CNNIC 45th Statistical Report on Internet Development in China.

[2]qu Ru, Yu Shanshan. A New Media in Government Affairs in Public Emergencies [J].Refuting Rumor Young journalists, 2020, (21): 49-50.

[3]Jiang Jing, Wang Wentao. Research on Government Dithering - Facing Public Emergence Public Opinion and Comparison with Government Weibo Intelligence magazine, 2020, 39(01): 100-106, 114.

[4]Guo Miao, Ma Wei. J. on the Role of New Media in Public Health Emergencies Young journalists, 2020, (24): $32-33$.

[5]Tong Feibo. Research on Development Status and Communication Strategy of Government Douyin Account [D]. Zhejiang University of Media and Communications,2019. 